\title{
PENERAPAN MODEL EVALUASI CIPP DALAM MENGEVALUASI PROGRAM LAYANAN PAUD HOLISTIK INTEGRATIF
}

\author{
Petrus Redy Partus Jaya, M.Pd. \& Felisitas Ndeot, M.Pd. \\ Program Studi PG PAUD STKIP Santu Paulus Ruteng \\ e-mail: petrusredypartusjaya@gmail.com, icananoarta@gmail.com
}

\begin{abstract}
This paper aims at designing the evaluation model CIPP in evaluating holistic integrative program services in early childhood education.A description of the terminology evaluation and evaluation of the program be placed on early so that the reader can see the holistic integrative services in early childhood education as a program.Next, elaborated on the model of evaluation of CIPP. An understanding of the four components of the CIPP evaluation be the key to implementing this model in evaluating program services holistic integrative in early childhood education.In the four components of the CIPP evaluation there are a few key questions: "what is needed?"; "what should I do?"; "is the program implemented?"; and "how the success rate of the program?".Shove off from these major questions, CIPP model can be applied to evaluate service program holistic integrative in early childhood education from the aspect of Context, Input, Process, and Product. The development of the object and questions of the evaluation refers to the Regulation of the President of the Republic of Indonesia Number 60 of 2013 and Technical Guidelines for the Implementation of Early Childhood Education (PAUD) at the PAUD Unit level.
\end{abstract}

Keywords: evaluation program, PAUD HI,CIPP evaluation model

\begin{abstract}
Abstrak :Tulisan ini bertujuan merancang model evaluasi CIPP dalam mengevaluasi program layanan PAUD HI ditingkat satuan PAUD. Uraian tentang terminologi evaluasi dan evaluasi program ditempatkan pada awal tulisan agar pembaca dapat melihat layanan PAUD HI sebagai suatu program. Selanjutnya, diuraikan tentang model evaluasi CIPP. Pemahaman tentang empat komponen evaluasi CIPP menjadi kunci untuk menerapkan model ini dalam mengevaluasi program layanan PAUD HI. Dalam empat komponen evaluasi CIPP terdapat beberapa pertanyaan kunci, yaitu "apa yang dibutuhkan?"; "apa yang harus dilakukan?"; "apakah program dilaksanakan?"; dan "bagaimana tingkat keberhasilan program?". Bertolak dari beberapa pertanyaan utama ini, model CIPP dapat diterapkan untuk mengevaluasi program layanan PAUD HI dari aspek Context, Input, Process, dan Product. Pengembangan objek dan pertanyaan evaluasi mengacu pada Peraturan Presiden Republik Indonesia Nomor 60 tahun 2013 dan Petunjuk Teknis Penyelenggaraan PAUD HI di tingkat Satuan PAUD.
\end{abstract}

Kata Kunci: evaluasi, program, PAUD HI, model evaluasi CIPP 


\section{PENDAHULUAN}

Evaluasi merupakan salah satu rangkaian penting dalam siklus perencanaan dan pelaksanaan suatu program. Tanpa evaluasi tidak dapat dipastikan ketercapaian tujuan program. Sebaliknya, dengan melakukan evaluasi tingkat ketercapaian tujuan suatu program dapat diketahui. Gambaran tentang tingkat keberhasilan suatu program memiliki efek signifikan terhadap keputusan dan langkah strategis yang akan diambil.

Program Layanan PAUD Holistik - Integratif (PAUD HI) telah dicanangkan pemerintah melalui Peraturan Presiden Nomor 60 tahun 2013. Praktisnya, program tersebut telah berjalan selama lebih dari 4 tahun. Idealisme yang menjadi latar belakang program ini adalah lahirnya generasi emas bangsa Indonesia yang sehat, cerdas, ceria dan berakhlak mulia (Pasal 2, Perpres Nomor 60 Tahun 2013). Generasi emas yang dicita-citakan ini akan menjadi kado spesial ulang tahun ke-100 bangsa Indonesia pada tahun 2045. Untuk itu perlu diidentifikasi sejak dini apakah program layanan PAUD HI yang sedang berjalan telah mulai mewujudkan cita-cita menyiapkan anak usia dini menjadi kado special bagi bangsa Indonesia? Jawaban atas pertanyaan ini dapat diketahui dengan melakukan evaluasi terhadap penyelenggaraan layanan PAUD HI.

Sejak tahun 2013, telah banyak dilakukan penelitian evaluatif terkait penyelenggaraan PAUD HI di tingkat satuan PAUD. Salah satu penelitian evaluatif dilakukan oleh Laila ( 2013, pp. 79-80) di PAUD Siwi Kencana, Kota Semarang. Dari penelitian evaluatif ini diperoleh informasi terkait kekuatan, peluang, kelemahan, dan tantangan penyelenggaraan PAUD HI di PAUD Siwi Kencana. Kekuatan yang dimiliki antara lain narasumber yang kompeten terkait penyelenggaraan PAUD HI dan tempat pembelajaran yang memadai; dari sisi peluang, PAUD Siwi Kencana telah menjalin komunikasi yang baik dengan orang tua. Selain kekuatan dan peluang, penyelenggaraan PAUD HI di PAUD Siwi Kencana juga memiliki kelemahan, diantaranya kondisi pembelajaran yang kurang kondusif, pertemuan dan materi pembelajaran yang terbatas. Selain itu, terdapat tantangan yang dihadapi PAUD Siwi, misalnya, orang tua kurang berani mengambil sikap tegas ketika anak 
sedang marah. Penelitian evaluatif ini selanjutnya dijadikan masukan bagi stakeholders untuk menyempurnakan penyelenggaran PAUD HI di PAUD Siwi Kencana.

$$
\text { Penyelenggaraan program }
$$
layanan PAUD HI di daerah lain juga perlu dievaluasi. Evaluasi ini penting untuk merumuskan rencana dan strategi yang tepat guna terselenggaranya layanan PAUD HI yang efektif dan efisien. Pemerintah telah memberikan peluang bagi setiap satuan PAUD untuk merancang bentuk penyelenggaraan PAUD HI yang sesuai konteks dan karakteristik satuan PAUD tersebut. Fleksibilitas penyelenggaraan PAUD HI akan efektif bila dilakukan kajian evaluasi yang komprehensif. Berdasarkan hasil pengamatan, penyelenggaraan PAUD HolistikIntegratif di Manggarai Raya masih belum terlihat jelas. Fakta ini diasumsikan terjadi akibat kurangnya pemahaman stakeholders dan penyelenggara PAUD di tingkat Satuan PAUD tentang PAUD HI. Selain itu, analisis konteks kebutuhan layanan PAUD HI, daya dukung sarana dan prasaranajuga belum dilakukan.Asumsi ini dapat dibuktikan dengan melakukan kajian evaluasi program layananPAUD
HI di Manggarai Raya. Mengingat penyelenggaraan program PAUD HI di Manggarai Raya masih tergolong baru, model evaluasi yang dapat digunakan adalah model evaluasi CIPP. Model evaluasi ini akan menghasilkan informasi menyeluruh terkait Context, Input, Process, dan Product program layanan PAUD Holistik-Integratif di Manggarai Raya.

\section{KAJIAN TEORI}

\section{Pengertian Evaluasi Program}

Term evaluasi memiliki beragam pengertian. Para pakar evaluasi mendefinisikan term tersebut dengan formulasi yang berbeda. Meskipun terdapat beragam definisi, inti formulasi tetap sama. The Joint Committee on Standards For Educational Evaluation memberi batasan istilah evaluasi sebagai kegiatan penyelidikan yang sistematis untuk menentukan nilai dan manfaat dari objek yang dievaluasi (Joint Committee on Standards for Educational Evaluation, 1994, p. 3).Fitzpatrick mengungkapkan bahwa evaluasi merupakan proses identifikasi, klarifikasi, dan penetapan kriteria untuk menentukan nilai (worth or merit) objek yang dievaluasi berdasarkan kriteria tersebut (Fitzpatrick, 2011, p. 7). 
Senada dengan pendapat Fitzpatrick, Daniel Stufflebeam mendefinisikan evaluasi sebagai proses mengumpulkan, menganalisis, dan melaporkan informasi deskriptif terkait nilai dari objek yang dievaluasi dalam rangka pengambilan keputusan dan meningkatkan pemahaman akan fenomena yang dievaluasi(Stufflebeam, 2007, p. 8). Dari beberapa definisi tersebut terlihat jelas bahwa evaluasi berkaitan dengan penentuan nilai danmanfaat (worth and merit) dari objek yang dievaluasi. Nilai dan manfaat yang telah ditentukan selanjutnya dijadikan sebagai informasi yang berguna dalam pengambilan keputusan.

Salah satu lingkup evaluasi adalah program-program yang diselenggarakan baik oleh pemerintah maupun oleh lembaga-lembaga lainnya. Evaluasi program adalah metode sistematik untuk mengumpulkan, menganalisis, dan memakai informasi untuk menjawab pertanyaan dasar mengenai program. Evaluasi program dapat dikelompokan menjadi evaluasi proses (process evaluation), evaluasi manfaat (outcome evaluation) dan evaluasi akibat (impact evaluation). Evaluasi proses meneliti dan menilai apakah intervensi atau layanan program telah dilaksanakan seperti yang direncanakan; dan apakah target populasi yang direncanakan telah dilayani. Evaluasi ini juga menilai mengenai strategi pelaksanaan program. Evaluasi manfaat meneliti, menilai, dan menentukan apakah program telah menghasilkan perubahan yang diharapkan. Salah satu model evaluasi program yang sering digunakan oleh para evaluator adalah model evaluasi CIPP. Model ini sering digunakan karena dianggap mampu memberikan informasi dan standar evaluasi yang komprehensif terkait program yang dievaluasi.

\section{MODEL EVALUASI CIPP}

Model evaluasi

CIPP dikembangkan oleh Daniel Stufflebeam pada tahun 1966. Stufflebeam menyatakan model evaluasi CIPP merupakan model evaluasi komprehensif yang memiliki fungsi formatif dan fungsi sumatif. Fungsi formatif evaluasi adalah memberikan informasi guna memperbaiki dan mengembangkan program sedangkan fungsi sumatif evaluasi adalah memberi pertimbangan untuk menentukan keberhasilan atau kelanjutan program (Stufflebeam \& Coryn, 2014, p. 315). 
Bila ditinjau dari waktu pelaksanaan evaluasi, William Dunn (1981, pp. 117120)menyebut kedua fungsi ini bersifat prospektif dan retrospektif. Sifat prospektif evaluasi berkaitan dengan fungsi formatif yang memberikan informasi sebelum dan saat program berlangsung. Sedangkan sifat retrospektif terkait dengan fungsi sumatif evaluasi yang memberikan informasi sesudah program dilaksanakan.

Nama CIPP dalam kenyataannya langsung menunjukkan karakteristik model evaluasi tersebut. CIPP adalah singkatan dari Context, Input, Process, dan Product. Dengan demikian terlihat bahwa model evaluasi CIPP terdiri dari empat komponenevaluasi, yaitu evaluasi konteks (Context Evaluation), evaluasi masukan (Input Evaluation), evaluasi proses (Process Evaluation), dan evaluasi produk (Product Evaluation). Keempat komponen evaluasi ini merupakan satu rangkaian yang utuh. Ini sebabnya model evaluasi CIPP disebut sebagai model evaluasi yang komprehensif. Meskipun demikian, Stufflebeam mengatakan bahwa dalam pelaksanaannya evaluator dapat menggunakan satu atau kombinasi dari dua atau lebih komponen evaluasi (Stufflebeam, 1983, p. 122). Setiap komponen dalam evaluasi CIPP terdiri dari fokus kajian yang berbeda. Evaluasi konteks (Context Evaluation) bertolak dari pertanyaan apa yang dibutuhkan? Tujuan evaluasi konteks adalah untuk mengetahui kekuatan dan kelemahan yang dimiliki evaluan (Stufflebeam, 1983, p. 128). Informasi terkait kekuatan dan kelemahan akan menentukan tindakan yang dapat dilakukan.

Komponen berikutnya dalam model evaluasi CIPP adalah evaluasi masukan (Input Evaluation). Evaluasi masukan membantu mengatur keputusan yang berkaitan dengan rencana dan strategi untuk mencapai tujuan. Fokus kajian evaluasi masukan meliputi: a) sumber daya manusia, b) sarana dan peralatan pendukung, c) dana/anggaran, dan d) berbagai prosedur dan aturan yang diperlukan (Widoyoko, 2014, p. 182).

\section{Evaluasi proses (Proccess}

Evaluation) dilakukan untuk memantau, mengumpulkan informasi dan menyusun laporan mengenai implementasi perencanaan program. Evaluasi ini menyediakan feedback atau masukan kepada stakeholders untuk 
menilai perkembangan program. Stakeholders dapat menggunakan informasi hasil evaluasi ini untuk mengetahui apakah terdapat kekurangan dalam pelaksanaan program, baik strategi maupun capaian program (Stufflebeam \& Coryn, 2014, p. 312).

Komponen evaluasi yang terakhir dalam model evaluasi CIPP adalah evaluasi produk (Product

Evaluation). Pada komponen ini, evaluator mengidentifikasi hasil pelaksanaan program, baik hasil jangka pendek maupun jangka panjang. Evaluasi ini mengukur keberhasilan program berdasarkan tujuan yang telah ditetapkan. Hasil evaluasi produk akan menjadi masukan bagi stakeholders untuk menentukan keberlanjutan program (Widoyoko, 2014, p. 183).

Evaluasi model CIPP pada dasarnya terkait dengan empat macam penilaian, yaitu: 1) menilai tujuan dan prioritas dengan membandingkannya dengan kebutuhan, masalah, dan peluang yang tersedia; 2) menilai rencana pelaksanaan dan anggaran yang dibutuhkan dengan membandingkannya dengan tujuan yang ditargetkan, 3) menilai efektivitas program, 4) menilai keberhasilan program dengan membandingkan hasil dan efek sampingnya dengan kebutuhan yang ditargetkan, memeriksa efektivitas biayanya, dan (mungkin) membandingkan biaya dan hasilnya dengan program yang kompetitif; juga dengan menginterpretasikan hasil-hasil yang menghambat pengeluaran upaya sumber daya dan sejauh mana rencana operasional itu baik dan efektif dilaksanakan(Stufflebeam \& Coryn, 2014, p. 315).

\section{PEMBAHASAN}

Dalam petunjuk teknis pelaksanaan PAUD HI, ditegaskan bahwa perlu dilakukan evaluasi terhadap pelaksanaan program layanan PAUD HI. Evaluasi pelaksanaan PAUD HI di satuan PAUD dilakukan oleh satuan PAUD yang bersangkutan dengan memanfaatkan data hasil instrumen pemantauan PAUD HI di satuan PAUD. Data evaluasi pada tingkat satuan PAUD dapat dijadikan sebagai bahan pemantauan dan evaluasi di tingkat kabupaten/kota, provinsi, dan pusat (Direktorat Pembinaan Pendidikan Anak Usia Dini, 2015, p. 21). Pelaksanaan evaluasi harus didasarkan pada pemahaman evaluator terkait objek yang akan dievaluasi. Oleh karena itu, ketika evaluator hendak 
mengevaluasi program layanan PAUD HI langkah awal yang dilakukan adalah mempelajari regulasi program layanan PAUD HI.

\section{REGULASI PROGRAM LAYANAN PAUD HOLISTIK-INTEGRATIF}

Program PAUD HI memiliki target ideal yaitu menghasilkan sumber daya manusia yang sehat, cerdas, dan produktif. Target tersebut dapat tercapai dengan mengoptimalkan perkembangan anak selama periode usia dini (lahir-6 tahun). Selain menetapkan cita-cita yang ideal, pemerintah juga menetapkan standar-standar peningkatan kualitas anak usia dini. Standar tersebut antara lain derajat kesehatan dan status gizi, kecerdasan dan keceriaan, kematangan emosional dan spiritual, dan kesejahteraan anak. Guna mencapai target tersebut, pemerintah menjamin pemenuhan hak tumbuh kembang anak usia dini melalui upaya peingkatan kesehatan, gizi, perawatan, pengasuhan, perlindungan, kesejahteraan, dan rangsangan pendidikan yang dilakukan secara simultan, sistematis, menyeluruh, terintegrasi dan berkesinambungan.

Pemerintah telah menguraikan program pengembangan anak usia dini Holistik Integratif di dalam Peraturan
Presiden Republik Indonesia Nomor 60 Tahun 2013. Perpres tersebut secara detail memuat informasi program PAUD HI. Informasi PAUD HI dalam Perpres nomor 60 tahun 2013 diuraikan ke dalam 8 Bab dan 22 pasal. Bab 1 memuat ketentuan umum yang menjelaskan tentang berbagai definisi terkait dengan penyelenggaraan PAUD $\mathrm{HI} ; B a b$ II menjelaskan tentang tujuan, prinsip dan arah kebijakan PAUD HI; Bab III tentang strategi, sasaran dan penyelenggaraan PAUD HI; Bab IV berbicara tentang gugus tugas pengembangan anak usia dini HolistikIntegratif; $\mathrm{Bab} \mathrm{V}$ tentang peran serta masyarakat; Bab VI: pelaporan; Bab VII: Pembiayaan; dan Bab VIII: Ketentuan Penutup.

Selain Perpres nomor 60 tahun 2013, Pemerintah melalui Direktorat Pembinaan Pendidikan Anak Usia Dini pada tahun 2015 telah menerbitkan Petunjuk Teknis (Juknis) penyelenggaraan PAUD HolistikIntegratif di Satuan PAUD. Juknis ini berisi Norma, Standar, Prosedur, dan Kriteria (NSPK) penyelenggaraan PAUD HI. Perpres Nomor 60 tahun 2013 dan Juknis Penyelenggaraan PAUD HI ini dapat dijadikan sebagai pegangan atau titik tolak 
penyelenggaraan PAUD HI di tingkat satuan PAUD. Selain itu, Satuan PAUD, pihak-pihak terkait, dan evaluator dalam memonitor dan melakukan evaluasi dapat berpedoman pada kedua regulasi ini.

\section{EVALUASI CIPP PROGRAM LAYANAN PAUD HI}

Evaluasi program PAUD HI di Satuan PAUD dapat dilakukan oleh satuan PAUD yang bersangkutan dengan berpegang pada Perpres Nomor 60 Tahun 2013 dan Petunjuk Teknis Penyelenggaraan PAUD HI. Dalam pelaksanaannya, setiap evaluator dapat memilih berbagai model evaluasi program. Namun, jika melihat kondisi penyelenggaraan PAUD HI yang masih samar-samar dan pemahaman yang belum memadai terkait PAUD HI, maka diperlukan suatu model evaluasi yang komprehensif. Model evaluasi yangdianggap paling tepat untuk mengevaluasi program ini adalah model evaluasi CIPP. Model evaluasi CIPP terdiri dari empat komponen evaluasi, yaitu context, input, process, dan product. Dengan berpegang pada regulasi, evaluator dapat merumuskan objek yang menjadi target evaluasi pada setiap komponen evaluasi model CIPP.
Selain itu, untuk mendapatkan informasi yang holistik evaluator perlu mengidentifikasi berbagai pihak (stakeholders) yang berkaitan dengan penyelenggaraan PAUD HI. Teknik pengumpulan data, teknik analisis data, penetapan kriteria evaluasi, dan target keputusan juga tidak boleh diabaikan oleh evaluator. Terkait dengan penetapan kriteria evaluasi, Stufflebeam mengatakan bahwa penentuan kriteria bergantung pada sudut pandang evaluator dan kesepakatan bersama antara evaluator dan stakeholders(Stufflebeam, 1985, p. 183).Berbagai komponen evaluasi ini perlu diperhatikan guna memperoleh informasi yang komprehensif dan menghasilkan rekomendasi yang konstruktif.

\section{EVALUASI KONTEKS (CONTEXT EVALUATION)}

Fokus evaluasi konteks adalah analisis kebutuhan (needs assestment). Pertanyaan utama dalam komponen ini adalah “apa yang dibutuhkan?”. Dalam konteks penyelenggaraan PAUD HI, pertanyaan utama tersebut dapat dikembangkan menjadi "apa yang dibutuhkan oleh anak usia dini di tingkat satuan PAUD yang dievaluasi?”. 
Informasi tentang beragam kebutuhan anak usia dini di lingkungan sekitar satuan PAUD dapat diperoleh dari berbagai pihak terkait, yaitu satuan PAUD, Dinas Pendidikan, Dinas Kesehatan, Dinas Sosial, BKKBN, Catatan Sipil, Badan Pemberdayaan Masyarakat, Polres/Polsek, Organisasi mitra, Posyandu, Tokoh Masyarakat, dan Orang tua. Berbagai pihak terkait ini dapat memberikan informasi tentang kebutuhan anak pada aspek pendidikan, kesehatan, gizi dan perawatan, parenting, perlindungan, dan kesejahteraan. Untuk mengumpulkan informasi atau data terkait, evaluator dapat menggunakan teknik Focus Group Disscussion (diskusi kelompok terfokus) dengan mengundang berbagai stakeholders PAUD untuk berdiskusi mengenai kebutuhan essensial anak usia dini di sekitar lingkungan satuan PAUD. Sementara itu, untuk menguatkan informasi, evaluator dapat melakukan triangulasi data dengan menggunakan teknik dokumentasi. Evaluator mengumpulkan berbagai dokumen tentang data kebutuhan anak usia dini dari pihak-pihak yang berkaitan dengan penyelenggaraan PAUD HI. Misalnya, data jumlah anak usia dini dapat diperoleh dari dinas catatan sipil; data kesehatan anak dapat diperoleh dari posyandu atau dinas kesehatan setempat; data perlindungan anak dapat diperoleh dari polres setempat; dan sebagainya. Berbagai input informasi hasil Focus Group Discussion(FGD) selanjutnya diolah menggunakan teknik analisis kualitatif model Miles \& Huberman (reduksi, display, dan penyimpulan). Penentuan kriteria evaluasi hasil FGD ini dilakukan dengan mengidentifikasi "kesamaan internal" dan "keragaman eksternal" data kualitatif yang telah dikumpulkan(Patton, 2009, p. 267).Sementara itu, data yang diperoleh dari dokumen pihak-pihak terkait dapat diolah menggunakan teknik analisis isi dan statistic deskriptif. Kondisi anak usia dini dapat diketahui dengan melihat angka rata-rata dan disajikan dalam bentuk tabel dan grafik. Penentuan kriteria evaluasi ini bersifat kuantitatif yaitu dengan membandingkan kondisi factual dan standar yang telah ditetapkan pemerintah melalui dinasdinas terkait. Misalnya, data factual tentang gizi anak usia dini dibandingkan dengan standar gizi bagi anak usia dini yang telah ditetapkan oleh dinas kesehatan. Perhitungan standar gizi anak dilakukan dengan metode 
antropometri yaitu dengan menghitung 1) berat badan; 2) tinggi (panjang) badan; 3) lingkar kepala; 4) lingkar lengan atas; dan 5) lipatan kulit (Solihin, 2017). Data evaluatif ini selanjutnya akan dijadikan pertimbangan dalam memutuskan prioritas layanan PAUD HI di tingkat satuan PAUD.

\section{EVALUASI MASUKAN (INPUT} EVALUATION)

Komponen evaluasi masukan memusatkan perhatian pada rencana dan strategi yang harus dilakukan. Pertanyaan utamanya adalah: "apa yang harus dilakukan (what should be done)?”. Rencana apa yang harus dilakukan oleh satuan PAUD?; lembaga/instansi apa saja yang terkait dengan satuan PAUD?; bagaimana koordinasi dan kerjasama satuan PAUD dengan instansi terkait?; Bagaimana program kerja dan Standard Operasional Procedure (SOP) penyelenggaraan PAUD HI di satuan PAUD?; bagaimana kompetensi tenaga pendidik satuan PAUD?; bagaimana ketersediaan sarana prasarana pendukung? dan, sumber dana/standar pembiayaan?. Setiap pertanyaan ini dapat dikembangkan lagi oleh evaluator.

Beragam pertanyaan evaluatif pada komponen input akan ditanyakan kepada berbagai pihak sesuai dengan kapasitas dan proporsi keterkaitan pihak tersebut dengan satuan PAUD. Data evaluasi komponen input dapat dikumpulkan menggunakan teknik Focus Group Discussion, dokumentasi, observasi, dan kuesioner.Dengan menggunakan teknik $F G D$, evaluator mendapat informasi yang menyeluruh, terbuka sekaligus kredibel terkait koordinasi, kerjasama satuan PAUD dengan instansi lain, sumber dana, standar pembiayaan dan bentuk keterlibatanstakeholders di luar satuan PAUD. Untuk menguji keabsahan data, evaluator dapat melakukan crosscheck dengan menggunakan teknik dokumentasi. Dokumen nota kesepahaman $(M o U)$ satuan PAUD dengan instansi lain serta dokumen SOP dan program kerja penyelenggaran PAUD HI merupakan dokumen penting yang dapat memberi informasi signifikan terkait rencana dan strategi penyelenggaraan PAUD HI.

Di samping FGD dan dokumentasi, pengumpulan data komponen input juga dapat dilakukan 
menggunakan teknik observasi dan kuesioner. Teknik observasi tepat bila digunakan untuk mengamati ketersediaan sarana dan peralatan penunjang. Sementara itu, teknik kuesioner dipakai untuk mengukur kompetensi tenaga pendidik pada tingkat satuan PAUD yang dievaluasi.

Hasil evaluasi komponen input dapat dianalisis menggunakan teknik analisis kualitatif model Miles \& Huberman dan teknik analisis statistic deskriptif. Olahan data ini akan menjadi sumbangan bermakna dalam memutuskan rencana dan strategi penyelenggaraan PAUD HI yang tepat di tingkat satuan PAUD. Apakah terpadu atau terpisah?

\section{EVALUASI PROSES (PROCESS EVALUATION)}

Fokus kajian komponen evaluasi proses adalah pelaksanaan program. Pertanyaan kuncinya: “Apakah program sedang dilaksanakan (Is it being done)?”. Program layanan PAUD HI terdiri dari 5 jenis layanan, yaitu: 1) layanan pendidikan; 2) layanan kesehatan, gizi, dan perawatan; 3) layanan pengasuhan; 4) layanan perlindungan; dan 5) layanan kesejahteraan. Objek evaluasi komponen proses adalah memastikan keterlaksanaan berbagai program layanan yang telah disebutkan berdasarkan skala prioritas yang telah ditentukan.Selain itu, objek evaluasi juga dapat berkaitan dengan model penyelenggaraan PAUD HI baik yang terpadu maupun terpisah.

Pertanyaan evaluasi dapat dikembangkan dengan mengacu pada petunjuk teknis (juknis) penyelenggaraan program layanan PAUD HI yang telah disediakan oleh Direktorat Pembinaan PAUD. Dalam juknis tersebut telah diuraikan dengan jelas aneka aspek pelaksanaan pada masing-masing program layanan PAUD HI. Berdasarkan aspek-aspek itu, evaluator dapat mengembangkan pertanyaan evaluasi. Misalnya, pertanyaan evaluasi terkait pelaksanaan layanan pengasuhan (parenting): "apa saja jenis kegiatan parenting yang dilakukan satuan PAUD dengan orang tua siswa?".

Teknik pengumpulan data pada komponen evaluasi ini adalah observasi dan dokumentasi. Observasi digunakan karena berbagai pertanyaan evaluasi pada komponen ini cenderung bersifat konkrit - faktual dengan kategori jawaban "ya" atau "tidak"; "ada" atau 
"tidak ada"; dan, "dilaksanakan" atau "tidak dilaksanakan". Sementara itu, teknik dokumentasi digunakan untuk menguatkan hasil pengamatan evaluator terkait penyelenggaraan PAUD HI di tingkat satuan PAUD.

Data observasi dianalisis menggunakan statistic deskriptif setelah data-data kualitatif dikonversi menjadi data kuantitatif dengan skala diskrit. Dengan cara ini, evaluator akan memperoleh gambaran persentasi pelaksanaan program PAUD $\mathrm{HI}$ di tingkat satuan PAUD. Data observasi juga dapat berupa data deskriptif kualitatif yang dapat diolah menggunakan teknik reduksi, display, dan penyimpulan. Data dokumentasi yang digunakan untuk menguatkan hasil observasi dianalisis menggunakan teknik analisis isi.

Evaluasi komponen proses bertujuan menetapkan strategi perbaikan dan pengembangan program. Bila hasil analisis data menunjukkan adanya kekurangan dalam pelaksanaan program, evaluator dapat memberi rekomendasi kepada stakeholders untuk merumuskan strategi perbaikan program. Sedangkan, bila program telah dilaksanakan sesuai rambu-rambu yang berlaku dan diidentifikasi akan mengalami keberhasilan, maka evaluator dapat menyarankan rencana pengembangan program layanan PAUD HI.

\section{EVALUASI PRODUK (PRODUCT} EVALUATION)

Komponen terakhir dalam model evaluasi CIPP adalah komponen evaluasi produk. Titik tolak evaluasi pada komponen ini terletak pada pertanyaan: "apakah program sukses (Did it success)?”. “Apakah program layanan PAUD Holistik - Integratif telah berhasil?". "Berapakah tingkat keberhasilan penyelenggaraan PAUD HI di satuan PAUD?". Ini adalah sejumlah pertanyaan yang menjadi focus kajian evaluasi komponen produk. Selanjutnya, pengembangan pertanyaan evaluasi mengacu pada indikator keberhasilan tiap layanan PAUD HI yang termuat dalam juknis penyelenggaran PAUD HI.

Pengukuran tingkat keberhasilan program dimulai dengan mengumpulkan data menggunakan teknik observasi, $F G D$, dan dokumentasi. Pada konteks ini, teknik observasi dapat menggunakan skala non diskrit untuk memperoleh data-data kuantitatif terkait keberhasilan setiap 
layanan program PAUD HI. Selain itu, evaluator juga perlu mengumpulkan data-data kualitatif yang menggambarkan persepsi berbagai pihak tentang keberhasilan program. Data-data kualitatif ini dapat diperoleh dengan melakukan diskusi kelompok terfokus $(F G D)$. Guna melengkapi informasi kuantitatif dan kualitatif, evaluator dapat menggunakan teknik dokumentasi. Dokumen yang dikumpulkan dapat berupa foto kegiatan layanan pendidikan, buku KMS/KIA, buku DDTK, dokumen kesepakatan satuan PAUD dengan orang tua terkait program parenting, dan sebagainya.

Informasi yang diperoleh pada komponen evaluasi produk dapat menjadi masukan untuk menentukan keberlanjutan program.Rumusan rekomendasi program layanan PAUD HI dapat ditentukan dengan mempertimbangkan kategori tingkat keberhasilan penyelenggaraan program. Apabila kategori tingkat keberhasilan program terdiri dari kategori rendah, sedang, tinggi, dan sangat tinggi, maka dapat disusun bentuk-bentuk rekomendasi sebagai berikut.

Tabel Bentuk Rekomendasi Hasil Evaluasi

\begin{tabular}{clc}
\hline $\begin{array}{c}\text { Kategori Tingkat } \\
\text { Keberhasilan }\end{array}$ & \multicolumn{3}{c}{ Bentuk Rekomendasi } \\
\hline \hline Rendah & $\begin{array}{l}\text { Memperbaiki perencanaan } \\
\text { penyelenggaraan program }\end{array}$ & dan strategi \\
Sedang & Meningkatkan kualitas penyelenggaran program \\
Tinggi & Mengembangkan program \\
Sangat Tinggi & . & \\
\hline
\end{tabular}

Tabel di atas membantu stakeholders untuk menentukan tindakan yang tepat berdasarkan evaluasi tingkat keberhasilan program. Apabila keberhasilan program berada pada tingkat rendah, maka tindakan yang harus dilakukan adalah memperbaiki perencanaan dan strategi penyelenggaraan program. Apabila tingkat keberhasilan program sedang dan tinggi, satuan PAUD dapat mengambil tindakan meningkatkan kualitas penyelenggaraan program. Bila keberhasilan program ada pada tingkat sangat tinggi, maka satuan PAUD dapat memutuskan untuk mengembangkan program. Berbagai bentuk rekomendasi 
dan tindakan ini tentu harus

keseluruhan aspek yang telah dievaluasi. Tindakan yang tepat harus berdasarkan evaluasi yang tepat dan komprehensif.

\section{KESIMPULAN}

Dalam evaluasi, pihak yang mengevaluasimenentukan nilai dan manfaat dari objek yang dievaluasi yang dijadikan sebagai informasi yang berguna dalam pengambilan keputusan. Hasilevaluasiakan dimaknai dengan angka dan dalam bentuk data deskriptif dalam rangka menghasilkan keputusan yang tepat. Misalnya, untuk melaksanakan kebijakan Pendidikan Anak Usia Dini Holistik Integratif, pemerintah melaksanakan program layanan PAUD HI yang mencakup layanan pendidikan, kesehatan, gizi, perawatan, pengasuhan, perlindungan dan kesejahteraan. Semua program tersebut perlu dievaluasi untuk menentukan apakah layanan atau intervensinya telah mencapai tujuan yang ditetapkan. Evaluasi program adalah metode sistematik untuk mengumpulkan, menganalisis, dan memakai informasi untuk menjawab pertanyaan dasar mengenai program. Salah satu model evaluasi program yang mempertimbangkan

sering digunakan oleh para evaluator adalah model evaluasi CIPP yang dikembangkan oleh Daniel Stufflebeam pada tahun 1966. Stufflebeam menyatakan model evaluasi CIPP merupakan model evaluasi komprehensif yang memiliki fungsi formatif dan fungsi sumatif. Fungsi formatif evaluasi adalah memberikan informasi guna memperbaiki dan mengembangkan program sedangkan fungsi sumatif evaluasi adalah memberi pertimbangan untuk menentukan keberhasilan atau kelanjutan program. CIPP adalah singkatan dari Context, Input, Process, dan Product. Dengan demikian terlihat bahwa model evaluasi CIPP terdiri dari empat komponen evaluasi, yaitu evaluasi konteks (Context Evaluation), evaluasi masukan (Input Evaluation), evaluasi proses (Process Evaluation), dan evaluasi produk (Product Evaluation). Evaluasi konteks (Context Evaluation) bertolak dari pertanyaan apa yang dibutuhkan? Evaluasi ini dilakukan dari keadaan awal. Evaluasi konteks mencoba memberi pertimbangan mengenai nilai dan arti dari suatu keadaan. Nilai diperlihatkan dengan mengemukakan mengenai keadaan evaluan. Tujuan 
evaluasi konteks adalah untuk mengetahui kekuatan dan kelemahan

kajian yang penting dalam mengambil pertimbangan terkait keberhasilan program. Evaluasi masukan membantu mengatur keputusan yang berkaitan dengan rencana dan strategi untuk mencapai tujuan. Fokus kajian evaluasi masukan meliputi: a) sumber daya manusia, b) sarana dan peralatan pendukung, c) dana/anggaran, dan d) berbagai prosedur dan aturan yang diperlukan. Evaluasi proses (Proccess Evaluation) dilakukan untuk memantau, mengumpulkan informasi dan menyusun laporan mengenai implementasi perencanaan program. Evaluasi ini menyediakan feedback atau masukan kepada stakeholders untuk menilai perkembangan program. Evaluasi proses dilakukan untuk mengetahui sampai sejauh mana rencana telah dilaksanakan dan komponen apa yang harus diperbaiki. Komponen evaluasi yang terakhir dalam model evaluasi CIPP adalah evaluasi produk (Product Evaluation). Pada komponen ini, evaluator mengidentifikasi hasil pelaksanaan program, baik hasil jangka pendek maupun jangka panjang. Evaluasi ini yang dimiliki evaluan.Evaluasi masukan (Input Evaluation) memiliki fokus

mengukur keberhasilan program berdasarkan tujuan yang telah ditetapkan. Hasil evaluasi produk akan menjadi masukan bagi stakeholders untuk menentukan keberlanjutan program. Keempat komponen tersebut apabila dibunakan untuk mengevaluasi kebijakan program layanan HI di PAUD akan mengacu padaPerpres Nomor 60 Tahun 2013 dan Petunjuk Teknis Penyelenggaraan PAUD HI.

Terdapat beragam model evaluasi yang dapat digunakan untuk mengevaluasi program. Namun, bila merujuk pada pelaksanaan program PAUD HI selama ini, model CIPP dianggap paling cocok untuk digunakan.Penulis mengharapkan, melalui tulisan ini, pihak-pihak yang ingin melakukan evaluasi program PAUD HI memperoleh gambaran yang jelas mengenai model evaluasi CIPPdan menerapkannya dalam mengevaluasi program PAUD HI.

\section{DAFTAR PUSTAKA}

Direktorat Pembinaan Pendidikan Anak Usia Dini. (2015). Petunjuk Teknis Penyelenggaraan PAUD Holistik Integratif di Satuan PAUD. Jakarta: 
Kementerian Pendidikan dan Kebudayaan.

Dunn, W. N. (1981). Public Policy Anaysis: An Introduction (Second Edition). New Jersey: Prentice Hall.

Fitzpatrick, J. L. (2011). Program Evaluation: Alternative Approaches and Practical Guidelines (4th edition). New Jersey: Pearson Education.

Joint Committee on Standards for Educational Evaluation. (1994). The Program Evaluation Standards. Thousand Oaks: CA: Press.

Laila, L.Z. (2013). Penyelenggaraan Program PAUD Holistik Integratif di PAUD Siwi Kencana Kota Semarang. Journal of Non Formal Education and Community Empowerment. 73 - 83.

Patton, M. Q. (2009). How to Use Qualitative Methods in Evaluation (Terj.). Yogyakarta: Pustaka Pelajar.

Peraturan Presiden Republik Indonesia Nomor 60 Tahun 2013 tentang Pengembangan Program Layanan Pendidikan Anak Usia Dini Holistik - Integratif.

Solihin, A. (2017, Agustus 25). Retrieved Mei 31, 2018, from blogspot: https://paudanakbermainbelajar.blogspot .com/2017/08/carapengukuran-dan-penilaianstatus.html
Stufflebeam, D. L. (2007). Evaluation, Theory, Models, \& Application. San Fransisco: CA: Whilley.

Stufflebeam, D.L., Coryn, Chris L.S.. (2014). Evaluation: Theory, Models, \& Application (Second Edition). San Fransisco: Jossey-Bass.

Stufflebeam, D. L. (1985). Systematic Evaluation. Masachusetts: KluwerNijhoff.

Stufflebeam, D.L., Madaus, G.F., Scriven, M.S.(1983). Evaluation Models: Viewpoints on Educational and Human Service Evaluation. Boston: KluwerNijhoff Publishing.

Sukardi. (2011). Evaluasi Pendidikan: Prinsip dan Operasionalisasinya. Jakarta : Bumi Aksara.

Widoyoko, E. P. (2014). Evaluasi Program Pembelajaran. Yogyakarta: Pustaka Pelajar. 